ISSN 2338-4778 (Print)

\title{
Using Life of Pi Novel to Promote Character Education in English Class
}

\author{
Anastasia Camelia Wardhani ${ }^{1}$, Ouda Teda Ena ${ }^{2}$ \\ *camegelia@gmail.com, ouda@usd.ac.id \\ ${ }^{1}$ Education and Teacher Training Faculty, Sanata Dharma University, Yogyakarta, Indonesia \\ 2 Education and Teacher Training Faculty, Sanata Dharma University, Yogyakarta, Indonesia
}

Received: 11 March 2020 Accepted: 29 May 2020

DOI: $10.24256 /$ ideas.v8i1.1257

\begin{abstract}
The objective of this research is to design English learning material for Junior High School in Indonesia. The material developed is intended as supplementary material to promote character education in English class. The material designed is based on Martel's Life of Pi novel published in 2001. This novel is about Pi's strategies to survive in the middle of the ocean and therefore it is suitable to promote character education. The developed material consists of four units. Each unit consists of reading, vocabulary, writing, group work and reflection. The four aspects of character education to learn are appreciate others, respect older people, be grateful and appreciate God's creatures. Unit I consists of activities and materials to promote appreciation for others. Unit II deals with respecting the elders. Unit III is designed to promote gratefulness. While Unit IV is aimed at appreciation of God's creatures. Research and Development is used as the method in conducting the study and designing the material. The instruments are including open-ended questionnaire, the themes found in "Life of Pi" Novel and one week observation during the English subject in the class. The developed material has been evaluated and deemed as very good after the revision. The tasks are considered as suitable for Junior High School students, the reading material is appropriate and the layout is interesting. The supplementary material is necessary due to the fact that the textbooks used in the Junior High School do not cover character education.
\end{abstract}

Keywords: character education; learning material; Life of Pi novel

\section{Introduction}

There are two reasons that underlie this study. First, based on the writer's experience, some students in a particular class in Junior High School have lack understanding to appreciate their teacher. They tend to reject the presence of the teacher and make the classroom activities run out of control. The students need 
support from their teacher in order to encourage them to be able to follow the activities in the classroom and solve the problem that might occur in the learning process.

The second reason of the study is based on the writer's personal experience when she was a Junior High School student. She tended to disrupt the learning activities and made her teacher gave up on her. It was because she did not like the teacher and she was facing a problem after losing her mother. She also thought that the learning process was boring and helpless.

Based on those experiences, the writer argues that in order to overcome the students' uncontrolled acts, the students need to learn character education. In this case, the way to deliver the character education included in the learning process in English subject. The writer's experiences become a reflection for her to motivate the students to focus on learning and help the students to appreciate their lives. Later, the writer designed the material to help the students to learn English better and also to give better understanding about themselves and their lives through character education.

Studies have shown that parents, peers, and teachers has an individual effect on motivation and engagement of the students. They affect academic performance, engagement and increased behavioral engagement (Mason, 2012). It means that in delivering the character education to the students in the class, the teacher needs to pay attention not only to the children themselves but also to the students' interaction with other students. It is hoped that the teacher is able to create interesting material. Through interesting materials, added with character education, the students are expected to not only learn English as the main subject but also gain insight about life's values which influence their character. Interesting materials are used to encourage the students to learn and make the learning process more fun. The materials about the character education are taken from Yann Martel's Life of Pi which teaches a lot of moral values and the values of life. Through character education, the students are expected to appreciate their lives and especially appreciate their teacher. In addition, a literary work provides some lessons or moral values through the characters ( Masruddin, 2018; Lisda, 2019)

The writer creates the designed material as supplementary instructional for the eighth grade students of Junior High School. It is supplementary because the writer wants to emphasize the character education as an affective part of learning which sometimes missed in the learning process.

In creating the designed material, the writer uses theories from Schoch (2013) and Dick and Carey (2009) for the students textbook. In the reflection part of the students' textbook, the writer uses theories from Kendall (as cited in Schoch, 2013). To understand the students' interest, the writer uses the theory of adolescence by Steinberg (2002). The understanding of adolescents' behavior is implemented in the making of the group work activity in the designed material.

The theory from Gwilliam (2012) is used as an evidence that "Life of Pi" Novel 
is good for students because of its moral values and it can be used to deliver character education. This theory used to create the reflection part of the designed material. In designing the reflection part for students textbook and the teachers' guidebook, the writer also uses theory from Mason (2012). Theory of motivation by Shuell (1986) and Barrows and Tamblyn (1980) are used to create the prologue part of the students textbook. Moreover, theory from Harden (2000) helps the writer to decide how to deliver the materials to the students as written in the teachers' guidebook. Theory of humanity by Pictet (1956) and theory of pedagogic competence by Irina (2011) also included to compile the reflection part and how to build good communication between teacher and students. "Pedagogical competences can be found in concrete terms with the other subcategories, such as communication and relationship in the classroom management." (p. 421). The designed material in this study also uses functional education theory to justify the character education included. According to Idowu in Udoh (2014), functional education also takes part in develop the students' affective ability.

\section{Method}

The method used in this research was R\&D (Research and Development). Godin (2001) explained that research meant an "act of searching closely and carefully", or "intensive searching" (p. 2). Therefore, the research conducted did not stop only on the research but also continued by the making of the designed material. The research was conducted in a particular Junior High School in Yogyakarta. The writer observed the eighth grade students of one class. This class chose based on the suggestions from senior teachers and the writer found some students had various personal problem which influenced their behavior in learning process. The research was conducted during the learning process in the classroom and English subject was the media to conduct this research. The participants of this research were 27 eighth grade students in a Junior High School. Besides, there were also three experts and three users as the evaluators of the learning material. The instruments used in this research were the themes found in "Life of Pi" Novel, one week observation during the English subject in the class. Questionnaire distribution aimed to find out the students' interest in learning English, reading, writing and their feeling during learning process in the classroom. The questionnaires form were close-ended questionnaire, open-ended questionnaire and likert scale both for students, users and experts.

There were several procedures in conducting this research. Firstly, the writer asked for permission letter from the university and the related school. Second, the writer did the observation in the class. Third, students were given the questionnaire to identify their interest and difficulties in learning English. Fourth, the writer analyzed the data from the questionnaires to create the learning material. The draft of the learning material then sent to the users and experts to be checked and then revised by the writer. 


\section{Results}

\section{The Developed Materials}

\section{Unit 1: My Very Bestfriend}

In Unit I, the theme is 'My Very Bestfriend'. The theme is chosen based on the result of the students' preferences taken from the questionnaire. The objective of the character education is to appreciate others and build a better relationship among friends. As written in the Life of Pi novel, Pi finally have built better relationship with Parker the tiger after they have got many problems in understanding each other. In the implementation later, the teacher is expected to decrease the gap among the students through the activities given.

\section{Unit 2: My Favorite Teacher}

In this unit, the objective of the character education is to appreciate and respect teachers. The purpose of the mentioned character education is related to the problem occurs in the particular class and also as written in the Life of Pi novel. In the novel, Pi has difficult time in the beginning when he tries to train Parker to respect him as Parker's mentor. Moreover, based on the writer observations, the students in the related class have lack sense of respect toward the teachers. Through the activities in this unit, the students are expected to be able to respect and appreciate their teachers.

\section{Unit 3: Every Thing Around Me}

In Unit III, the objective of the character education is to be grateful for what the students have in their lives. This character education is related to the problems faced by the students in the particular class. The teacher is expected to teach the students to be grateful for everything around them and do not considered problems as an obstacle.

\section{Unit 4: Wild Wild Life}

In Unit IV, the objective of the character education is to develop the students' awareness to protect nature. This character education is chose based on the themed desired by the students. It is also related to the theme in Life of Pi novel where Pi lives near to the zoo runs by his father. He also participates in taking care of the animals in the zoo. It is expected that the teacher is able to deliver a message to the students about the importance of protecting the nature and environment.

\section{Stakeholders Perceptions on the Developed Materials}

Tasks

In the tasks part, based on the evaluation from the users and experts, the instruction and the level of difficulty of the activities given are already appropriate. 
The writing space provided and the theme presented in each unit also agreed by the users and the experts. Related to the character education discussed, the users and the experts agree that the learning material can motivates the students to learn English. Besides, it is approved that the reflection part also helps the students to recognize their ability in learning English.

\section{Readings}

In reading parts, it is suggested by the users and the experts to simplified the passages and adjust to the mastery of English for the students. Furthermore, most of the users and the experts agree that the length of the passages, the vocabulary utilized and the comprehension questions provided are appropriate for the students.

\section{Layout}

In this part, there are five considerations raised by the writer. According to the evaluation of the users and the experts, the font size, the appropriateness of the pictures presented and the title of each part (reading, writing, vocabulary and reflection) are interesting for the students. Moreover, it is agreed by the users and experts that the pictures provided in the units motivate the students to learn. The emoticons used in the reflection part also considered as helpful for the students to express their feelings.

\section{Discussion}

Based on the questionnaires distributed to the students and the data analyzed from the questionnaires, the writer compiles the learning material. The writer creates students textbook and teachers' guidebook. After reading and understanding the answers and the suggestions from the users and experts, the writer starts to create the final design of the material. For the activities in the students' textbook, the writer gives more interesting activities such as interviewing teacher and making handcraft for the students' favorite teacher. The writer also inserts the part of speech for each word in the list of the vocabularies. As suggested by the users and experts, the writer also simplifies the passages in the units.

The themes used in each unit of the students textbook are compiled based on the students' interest analyzed in the questionnaire. In each unit, the students also learn about character education in implicit way. There is different purpose of character education in each unit. In the teachers' guidebook, the teacher is expected to accompany the students during the learning process. In the prologue part of Unit I up to Unit IV, the teacher is expected to motivate the students through opening question such as "How are you?" and asked the students about something related to the pictures in the particular unit in order to brainstorm the students to be ready to engage in the learning process. 
In the reading part of Unit I until Unit IV, the teacher is expected to help the students in answering the comprehension questions related to the passage given. The teacher can also help the students by translating some difficult words.

In the vocabulary part of all units, the teacher is expected to accompany the students during their activity in matching or translating vocabulary from English to Indonesian. In the writing part, the teacher is expected to help the students to arrange correct English sentences. The writer also provides group work part in the learning material which related to the theory about supportive relationship by Harden (2000) and theory of adolescent behavior by Steinberg (2002).

In the reflection part of each unit, the teacher is expected to encourage the students to feel free in expressing their feeling during the learning process. The role of the teacher is to convince the students to be honest in writing down their feelings. In this part, it was very important for the teacher to inform that the students' answers will not influence their academic score. The character education included in this learning material is related to Kurikulum 2013. The part of the curriculum is the basic competence in the basic competence in the English subject. The basic competences mentioned are (p. 6):

1. Appreciate others and care in doing the communication with friends and teacher.

2. Appreciate honesty, discipline, confident and be responsible in doing the communication with teacher and friends.

3. Appreciate responsibility, compassion, teamwork and peacefulness in doing functional communication.

In addition, the writer also provides the objective of the character education of each unit to make sure the teacher understands the purpose of the related character education.

\section{Conclusion}

The Life of Pi novel is suitable as a source to develop learning material to promote character education. There are four units developed from the novel in this study. These units may promote four aspects of character education, namely appreciating others, respecting elders, being grateful and appreciating God's creatures. The reviews of the material from experts and users show that the material is acceptable to use for Junior High School students.

For the future research, it is recommended to utilize novel as source of learning, especially English. It is also recommended for English teacher to implement this learning material in the classroom for Junior High School students. 


\section{References}

Coupland, R. (2001). Humanity: What is it and how does it influence international law? [Electronic version],International Review of The Red Cross, 83, 969-989.

Dick, W., Carey, L., Carey, J. O. (2009). The systematic design of instruction. Pearson : London

Godin,B. (2001). Defining R\&D: Is research always systematic? Retrieved December 14, 2014, from http://www.csiic.ca/PDF/Godin_7.pdf

Gwilliam.2012. Concept analysis of life of pi [Review of the book Life of Pi] [Electronic version]. $B Y U, 1-10$.

Harden, R.M. (2000). The good teacher is more than a lecturer-the twelve roles of the teacher. [Electronic version] AMEE : UK

Kementrian Pendidikan dan Kebudayaan. (2014). When english rings a bell

Laidlaw, S. (2012). Top 10 teaching tips for middle school math.Retrieved December 12, 2014, from http://www.imagineeducation.org/downloads/consulting.pdf

Lickona, T. (2001). The teacher's role in character education. Retrieved June 10, 2014, from http://www.fasper.bg.ac.rs/nastavnici/Matejic DJ Zorica/doktorske/Stilovi\% 20vaspitanja\%20dece\%20ometene\%20u\%20razvoju/RADOVI/214302.pdf

Lisda, L. (2019). Re-Affirming Englishness: Ultimate Half-Ness and (Critical) Multiculturalism in Billy Bragg's England, Half English. IDEAS: Journal on English Language Teaching and Learning, Linguistics and Literature, 7(1). doi:https://doi.org/10.24256/ideas.v7i1.72

Mason, M.M. (2012). Motivation, Satisfaction, and Innate Psychological Needs. International Journal of Doctoral Studies Volume 7, 2012.

Masruddin, M. (2018). Lessons in Old Man and the Sea. IDEAS: Journal on English Language Teaching and Learning, Linguistics and Literature, 1(1). doi:https://doi.org/10.24256/ideas.v1i1.126

Martel,Y. (2001). Life of pi. Harcourt Books : USA

Milne, I. M. (2008). Novels for students. [Electronic version] GALE : USA

Mishan, F. (2005). Designing authenticity intolanguage learning materials. [Electronic version] Intellect : UK

Schoch, K. (2013). How to teach a novel.Retrieved October 16, 2014, from http://teachingreadingandla.pbworks.com/f/How_to_Teach_a_Novel_45_pp.p $d f$

Steinberg, L. (2002).Adolescence sixth edition .McGraw-Hill:New York

Udoh, Okon. A. (2014). Functional education : rising vocational skill requirements in a global economy.IMPACT : IJRHAL, 2. 143-150

Webber, J. (2006). Sartre's theory of character. European Journal of Philosophy, 14(1), 94-116. 


\section{Appendix}

\section{My Very Best Friend}

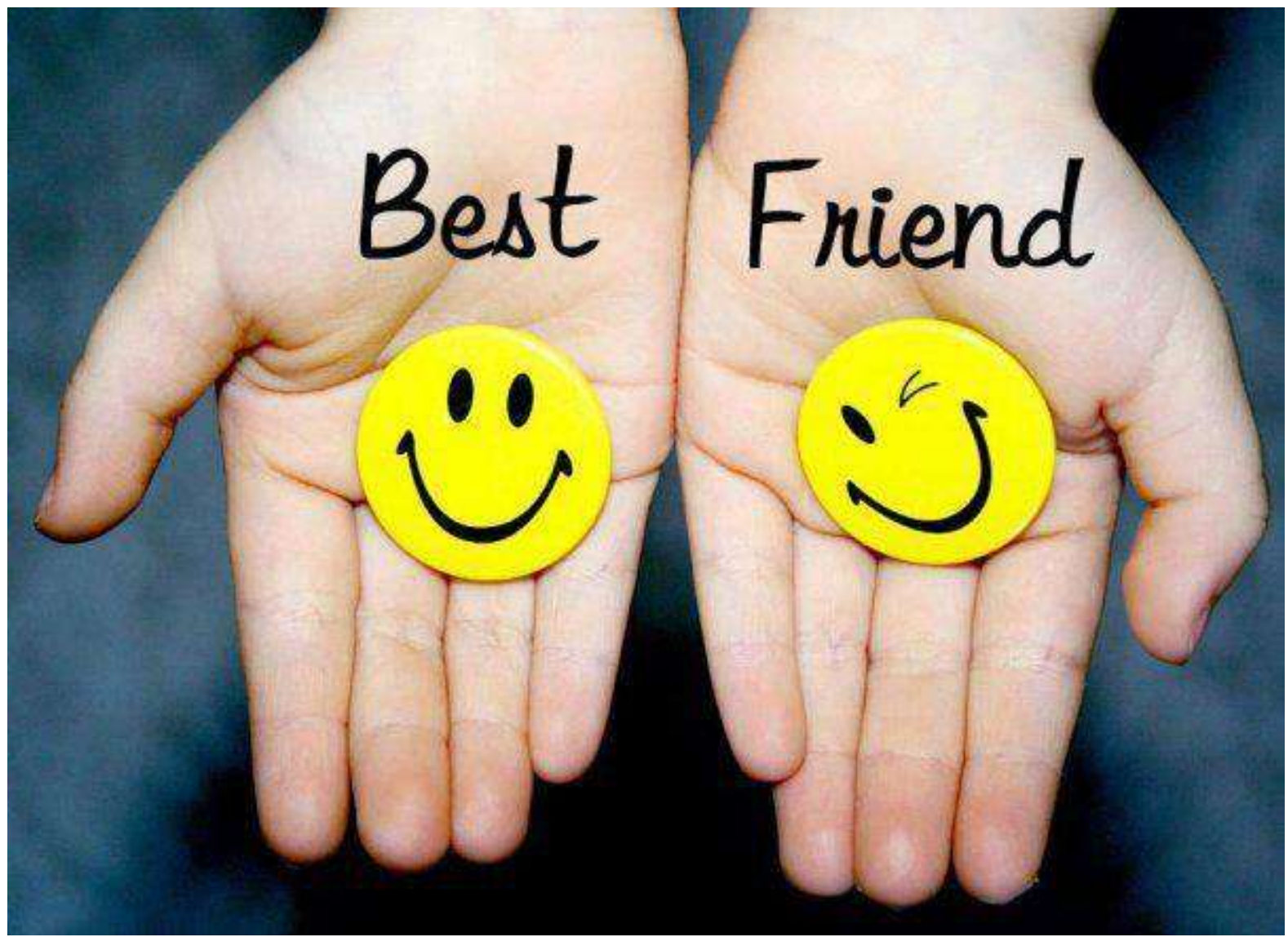

Theme : Friendship

In this unit, students are able to :

- Answers questions related with passage provided using English

- Knowing and understanding new English vocabularies

- Writing the experience they had with they bestfriend using English appropriately

- Interview their friends using good English

- Have better communication with friends 


\section{UNIT I}

\section{My Very Bestfriend}

Do you have bestfriend(s)? How many bestfriends do you have? We all have that friends that really know about us. Maybe they have lots of similarities with us or maybe they are always there to help us. It is always nice to have bestfriends, right? Do you tell your secrets to your bestfriend? A bestfriend is someone who you can trust, someone who never gets tired to hear your story and always have their shoulder for you to cry on. Do you love your bestfriend? If yes, tell them now!

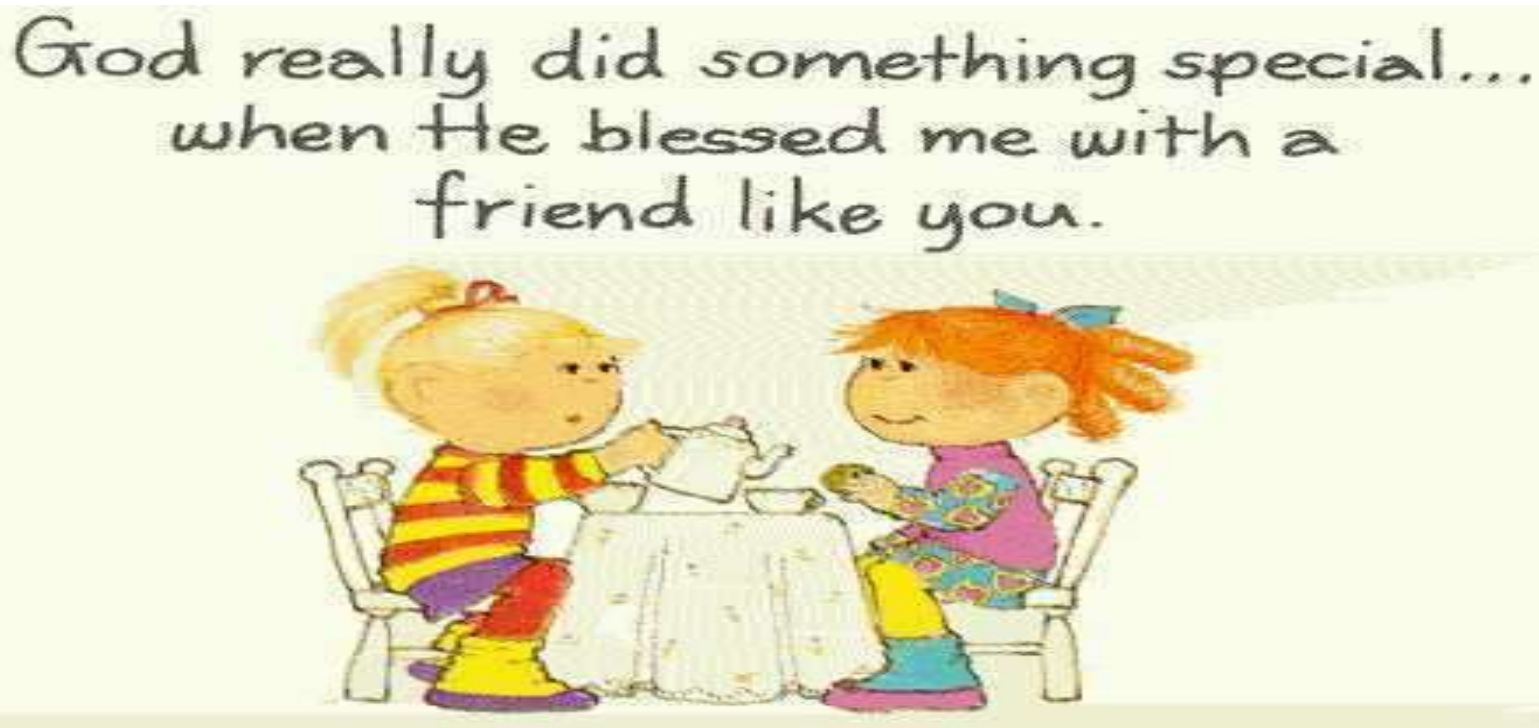

\section{A. Yeay, It's Reading Time!}

It was Richard Parker who calmed me down. It is the irony of this story that the one who scared me witless to start with was the very same who brought me peace, purpose, I dare say even wholeness.

We were, literaly and figuratively, in the same boat. We would live-or we would die-together. But there's more to it. I will come clean. I will tell you a secret : a part of me was glad about Richard Parker. A part of me did not want Richard Parker to die at all, because if he died I would be left alone with despair. If I still had the will to live, it was because of Richard Parker. He kept me from thinking too much about my family and my tragic circumstances. He pushed me to go on living. I hated him for it, yet at the same time I was grateful. I am grateful. It's the plain truth : without Richard Parker, I wouldn't be alive today to tell you my story. 
Using Life of Pi Novel to Promote Charactr Education in English Class

After reading the passage above, try to answer these following questions!

1. Who lived in the boat with the writer?

2. What was the writer's secret?

3. Why the writer felt so grateful to have Richard Parker in the boat?

\section{B. I Want to Know More!}

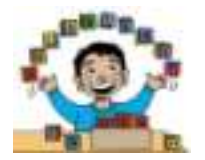

Match the English words on the left to its meaning in Indonesian on the right!

Circumstances(N)

Secara kiasan

Come clean(V)

Mengaku

Witless(adj)

Sesungguhnya

Literally(adj)

Dungu

Figuratively(adj)

Keputusasaan

Despair(adj)

Keadaan

\section{I Want to Tell You Something}

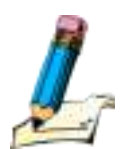

Please share your unforgettable moment with your bestfriend(s) in the box below! 
IDEAS, Vol. 8, No. 1, June 2020

ISSN 2338-4778 (Print) ISSN 2548-4192 (Online)

D. Let's Work Together

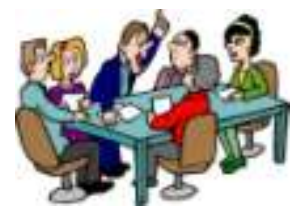

Find your bestfriend and fill the table together with your bestfriend! You can have more than one bestfriends

\section{Table of Friendship}

My Name

\begin{tabular}{|c|c|c|c|c|c|}
\hline No & Statement & Budi & $\ldots \ldots .$. & $\ldots \ldots .$. & \\
\hline $\mathbf{1}$ & First met & July 2013 & & & \\
\hline $\mathbf{2}$ & Bestfriend since... & August 2013 & & & \\
\hline $\mathbf{3}$ & Hobby & Swimming & & & \\
\hline $\mathbf{4}$ & He/she is the best at... & Cooking & & & \\
\hline $\mathbf{5}$ & I love him/her because... & He cares so much & & & \\
\hline $\mathbf{6}$ & We have a dream to... & $\begin{array}{c}\text { Travel aroung the } \\
\text { world }\end{array}$ & & & \\
\hline
\end{tabular}

\section{E. What Have I Learned This Far?}

Answer these following questions based on your learning experience!

1. What makes the learning easy for you?

2. What makes the learning difficult for you?

3. What do you still need to know before we move on? 
4. What have you learned from the activities in this unit?

5. How do you feel when you learned this unit? Please choose the emoticon(s) below by put- ting a tick on the place provided!
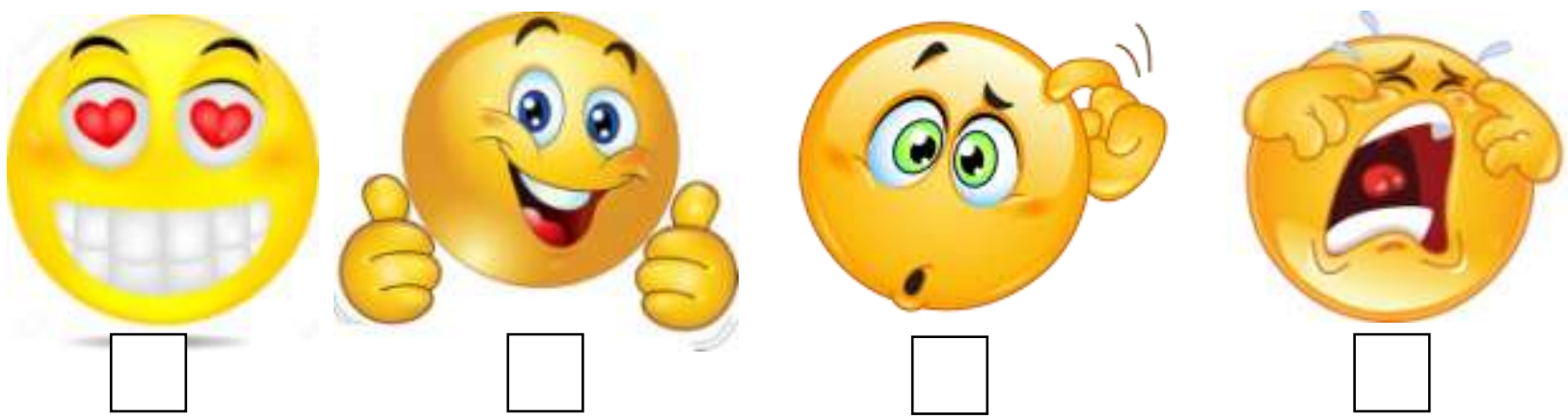

Please write the reason in this box

6. What do you want to do for yourself after knowing new knowledge from all of the activities in this unit? 